\title{
Investigating Indonesian Novice EFL Teachers' Perceptions On Their Identity Construction
}

\author{
Kristian Florensio Wijaya \\ kristianwijaya500@gmail.com \\ Sanata Dharma University, Yogyakarta
}

\begin{abstract}
Previous studies indicated that the majority of second language teachers were in serious hurdles in reconstructing their identities formation. The major hurdles that matter most in this debilitating inhibition are the lack of extensive emotional supports, minimum exposure of teaching ownership, and contradicting educational paradigms. This qualitative study aimed to further investigate Indonesian novice EFL teachers' perceptions of their identity construction. To gather reliable data, the critical incident technique manifested in the form of seven critical self-reflection inquiries were being asked to 3 invited novice EFL teachers possessing a vast range of teaching experiences resided in various Indonesian educational institutions. Three major themes were drawn from the interviewees' excerpts namely the importance of inducing more proactive teaching-learning engagement, establishing mutual rapports with learners as well as working colleagues, and rejuvenating the ongoing professional identity construction aligned with external institutional demands.
\end{abstract}

Keywords: Teacher Identity, Professional Identity, Critical Incident Technique

\section{Article Info}

Received date: 3 April $2021 \quad$ Revised date: 17 November $2021 \quad$ Accepted date: 27 Januari 2022

\section{INTRODUCTION}

To be more qualified, passionate, and compassionate educators amid abrupt educational shifts, teachers are commissioned to construct, reconstruct, and preserve their authentic identities establishment. On the contrary, the tangible trajectories to elevate teachers' identities had bear a huge brunt due to the dynamic constructions forming in this long-lengthy process and external forces enforced by the school institutions such as political, social, and cultural factors. All of these nature of identity construction is inextricably associated with the theory of teacher identities proffered by Reeves (2018) mentioning that robust identities constructed by teachers depend heavily on both internal and external forces eventually leading teachers to position themselves of becoming the coveted educators they aim to be.

Concerning this highly identities dynamic construction, it is of critical importance for educational institutions along with teacher training and education program to provide ample opportunities for teachers in which they can forge their identities construction more meaningfully. This particular suggestion seems fit to the main investigation conducted in this present study as novice EFL teachers are the figures who frequently undergone laborious, pain-staking, and energy-draining educational dynamics obstructions finally leading them to disregard their identities to fulfill their lofty calling as educators. Thomas and Beauchamp (2011) strongly accentuated the essentialism of internalizing more intensive identities training for novice EFL teachers to readily prepare them to be more tenacious, dedicated, and professional educators bravely coping with varied educational hurdles in their future teaching vocation. Thus, it can also be said that novice EFL teachers inhabit high-risk educational enterprises in reshaping their identities compared to experienced EFL teachers due to the intense social, affective, and psychological supports imparted by the school institutions together with continual mutual trust entrenched within the senior EFL teachers' work fields. All of these lines of arguments are closely interlinked with the major finding of senior and novice EFL teachers' identity construction study plied by Farrell (2011) unveiling that experienced EFL teachers underwent easier educational ventures in their career pathways since their educational institutions had entrusted, appreciated, and provided all of the rewarding external resources beneficial for empowering their further identities construction. 
In the same vein, the robust establishment of identity is also very much in line with the current roles EFL teachers play in their existing school institutions. Thus, EFL teachers are required to renew their professional identity continuously in order to promote more meaningful teaching-learning processes for learners. Kayi-Aydar (2019) propounded that a higher level of professional identity can enable EFL teachers to become more transformative educators. Dikilitas and Yayli (2018) together with Kumazawa (2013) also mentioned that EFL teachers' personal and professional beliefs have to be closely correlated to create more holistic educational climates. On the contrary, the pathway to be more professional educators possessing robust identities has approached acute obstacles, particularly for EFL teachers who firstly entered their teaching vocation with a minimum educational experience. Those hazardous impediments manifested in the forms of internal and external constraints. The internal constraints may arise from the classroom learning circumstances where teachers habitually dealing with non-compliant learners' behaviors and learning disengagement. While the external constrain potentially inhibiting EFL teachers' identities constructions can be visibly unearthed in the forms of unsupportive working environments, lack of social supports from school institutions, and inability to fulfill the school expectations. All of these identity construction hindrances are congruent with the previous major finding of EFL teachers' identity construction study conducted by Kumazawa (2013), Miyahara (2015), and Schaefer (2013) unfolded that the majority of novice EFL teachers cohort frequently faced both the internal and external constraints impeding their identities construction noticeable in the forms of unruly learners' behaviors, adverse working vicinities, the dearth of external supports given by the school institutions, and the mismatch between their expectations with the realities they experienced in their working places.

To minimize all of these impediments, EFL teachers are also advocated to nurture their identity construction by establishing a more mutual collaborative networking with all educational stakeholders. Kumazawa (2013), Livingston (2016), and Miyahara (2015) stated that educational institutions to collaboratively work with EFL teachers to devise new curriculum, school policies, and educational practices suit the teaching-learning dynamics in their school institutions. EFL teachers are also strongly suggested to become more adaptable toward rapid educational shifts happening in this modern age. Dikilitas and Yayli (2018) highly recommended educational parties to conduct an intensive professional identity training to arm EFL teachers with adequate knowledge of harnessing the specific pedagogical approaches in line with the educational objectivities.

5 relevant prior studies about EFL teachers' identity construction have been conducted in Indonesia. The first study was conducted by Mawardi (2012) discovered that the majority of teachers teaching civics education were advocated to proactively involve in designing teaching-learning materials, curriculum enactment, and classroom policies suit their teaching-learning situations to fully promote meaningful educational practices. In the second study, Kuswandono (2014) found out that the embedded self-reflective practices incorporated in teacher training and education faculties were frequently hampered by mistrust among teacher colleagues, which suggested that mutual and genuine trust among novice EFL teachers should be rebuilt to utilize the self-reflective practices in a more meaningful manner. Further, Avillanova and Kuswandono (2019) also unearthed that teacher professional development training should be induced at the commencement of teaching and education training faculties to breed more competent and professional teachers successful in translating all of the designated educational policies, curriculums, and beliefs into the right teaching-learning practices. Diasti (2021) also revealed that Indonesian novice EFL teachers frequently encountered serious internal and external obstructions while attempting to elevate their professional identities in terms of personal, interpersonal, and organizational factors. Hence, the researcher suggested educational practitioners sustainably providing intensive external supports for these EFL teachers to foster their identity constructions. In the last study, Diasti (2020) also advised EFL teachers to internalize self-reflective practices into their habitual teaching-learning practices to better prepare them to be more resilient educators insusceptible to a vast array of educational hindrances discovered in their classroom learning vicinities. Despite the significant research findings yielded by these 5 aforementioned studies inextricably associated with teacher identity constructions, none of these studies have profoundly investigated how Indonesian novice EFL teachers perceive their identity construction in the light of varied ELT enterprises. To fill this gap, this study was conducted to give a new enlightenment concerning the importance of preserving EFL teachers' identity amid various educational challenges. Two research problems were formulated as follows: (1) What are the specific advantageous sources 
sustaining novice EFL teachers to maintain their identity construction? (2) How do EFL teachers construct their identities amid unpredictable educational shifts?

\section{LITERATURE}

\section{The Utilization of Narrative Inquiry for Novice EFL Teachers' Further Identity construction}

Through the narrative inquiry approach, novice EFL teachers will potentially establish, rejuvenate, and substantiate their identity construction more holistically since they can exhaustively reflect on their own educational experiences in the light of social-cultural backgrounds and renewable insights found out in their proactive inquiries regarding their stories. Patton and Parker (2017) argued that the major purpose of narrative inquiry is to enable EFL teachers to delineate their tangible teaching experiences by harnessing more overarching social, cultural, and real-life angles. Concerning this definition and paramount role of narrative inquiry, novice EFL teachers are prompted to incorporate narrative inquiry as one of the compulsory rituals in their habitual educational practices to raise their profound awareness regarding the ideal educational constructions they should incorporate in their dailybased classroom practices eventually assisting them to construct their obvious portrayals of identities manifested in the forms of high-quality teaching-learning practices and continuous developing targeted competencies as professional educators. All of these potential rewarding merits bring about by narrative inquiry are intricately intertwined with the major benefit of narrative inquiry postulated by Clandinin, Caine, and Steeves (2013) believing that through narrative inquiry, EFL teachers are capable of disseminating their tangible teaching-learning experiences embodying in the forms of inspirational stories encouraging other colleagues to bring about the similar influential transformation in their teaching vocation as well. In a similar tone, Farrell (2012) also suggested novice EFL teachers seriously conduct more reflective practices manifested in the narrative constructions at the onset of their teaching careers to better assist them to locate their personal teaching goals, beliefs, and practices in accord with deep-rooted educational traditions entrenched by their school institutions, and most importantly they will be more life-long learners continually reflect on their knowledge of subject-specific skills and pedagogical competencies to promote significant influences for their classroom learning circumstances. Through the activation of narrative inquiry, novice EFL teachers can also potentially transform into more self-initiators, agentic, and proactive educational influencers in their particular educational institutions due to the overarching discovery of tangible meaning regarding the essentialism of becoming qualified educators in the presence of learners. Concerning these dynamic and intricate processes, EFL teachers may constantly renew their identity formation by ruminating more exhaustively over the internal and external streams that amplify or cripple their identity development. Hence, EFL teachers may gain richer educational experiences through the recollections of prior teaching-learning enterprises they have undergone beforehand since their stories are interpretative, complex, and subject to change in accord with their ongoing identity construction. Intertwining with all of these complex constructions of identity formation in the enlightenment of narrative inquiry, Golombek and Doran (2014) argued that EFL teachers can potentially establish a more powerful sense of identity formation throughout narrative inquiry since they are capable of amending their personal beliefs, internal subjectivity, and desired educational objectivities in accord with deep-rooted educational traditions inculcated by particular school institutions. Concerning this conception, Canagarajah (2012) also mentioned that identity construction plied through the inducement of narrative inquiry approach will allow EFL teachers to be more autonomous decision-makers, agentic agents of changes, and critical planners adept in interplaying their identity formation construction along with fluid educational beliefs forming in their educational experiences. Oxford and Cuelllar (2018) also asserted that narrative inquiry is one of the most complete interpretative qualitative research approaches wherein the researchers can obtain the specific educational portrayals expounding EFL teachers' tangible educational praxis may come to the fore of profound critical self-reflections reinforcing their specific educational beliefs throughout the whole teaching-learning communities.

\section{EFL Teachers' Identity Construction}

Globalized ELT studies investigating EFL teachers' identity construction have proliferated in these recent decades. As evidenced by studies of experienced and novice EFL teachers in constructing their identities amid socio-cultural, political, and ever-changing educational dynamics conducted by Lindahl and Yazan (2019) as well as Song (2016) discovering that the majority of experienced and 
novice EFL teachers struggling more extensively in corroborating their identities in the complexities of teacher training and educational programs, ongoing professional development training, knowledge of subject-specific fields, and pedagogical competencies. Concerning these above-mentioned complexities, it is of critical importance to define here that EFL teachers' identity construction refers to the mutual interplays among personal, professional, external complexities experienced by teachers throughout their teaching careers, strongly influenced by significant others working in similar educational surroundings comprising of senior teachers, school principals, working colleagues, learners, parents, and school administrators. Martel and Wang (2015) exclaimed that the further development of EFL teachers' identity construction are cogently affected by both internal and external constructions enshrouding of perceived responsibilities to play their new roles as language teachers together with external social supports addressed by school teaching-learning communities consisting of experienced teachers, school principals, working counterparts, students, parents, and administrators. To fully embody the robust construction of EFL teachers' identities, second language teachers' identity constructions should be pondered more meticulously in the light of other influential complex elements like professional beliefs, values, personalities, perspectives, socio-cultural, political, and current educational institutions' demands. All of these globalized ELT complexities seem fit with the seminal works of indispensable factors influencing EFL teachers' identity construction generated by Barkhuizen (2017) unearthed that nearly all of the EFL teachers have transformed into more agentic agents of changes possessing more robust identity construction after being exposed to prior professional practices encompassing of the specific teaching-learning experiences they have undergone along with diverse teaching-learning conditions. They continued that another essential predictive factor believing to sustain EFL teachers' further identity construction denotes contextual educational frameworks erected in their classroom learning vicinities consisting of educational paradigms tensions involving teachers and school stakeholders, socio-cultural values forming in their learning communities, and superior educational beliefs forming in their educational institutions. As revealed by all of these indispensable globalized ELT constructions perhaps sustaining further EFL teachers' identity construction, it is iterative to worth suggesting that all school teaching-learning community members should transform into more supportive, attentive, and continual educational supporters for all EFL teachers to continue infusing, fostering, and bolstering their identity construction by proffering a vast array of self-reflective teaching-learning practices helpful in assisting them to create clearer red linen between their prior, present, and future teaching along with working experiences specifically rewarding for their developing identity formation as well as educational practices they internalized in their specific classroom learning contexts. Darvin and Norton (2015) as together with Kanno and Stuart (2011) strongly advocated school institutions to be responsive and supportive for the further development of EFL teachers' identity construction by investing more intimate rapports, intensive identity practices, and critical self-reflection practices sustainably to better enact more solid identity establishment wherein all teachers experience a higher level of self-belonging, commitment, and dedication toward their particular teaching-learning communities.

\section{RESEARCH METHODOLOGY}

Methodologically speaking, this present qualitative study aimed to investigate Indonesian novice EFL teachers' perceptions of their identity construction. To comply with this research objectivity, the critical incident was also employed to obtain more overarching and trustworthy data throughout the stories told by the research participants. Daley et al. (2018) mentioned critical incident as a qualitative research approach functioned to assist researchers to obtain more in-depth overviews out of the meaningful and impactful stories recited by the participants. 7 in-depth self-reflective inquiries were also harnessed in this case study to ascertain the reliability of the data gathering processes. Three novice EFL teachers studying at English Education Master Students, Sanata Dharma University also took part in this case study. A case study is beneficial to reveal the intended data told by the research participants since the tangible life events will be more relevant with the designated research area. At this present moment, two of them are still working for formal English Language Institutions resided in Yogyakarta City. While one participant possessed a minimum number of teaching exposure since she only experienced one particular teaching practicum placement taking place for one month in a state school institution located in Yogyakarta City. The data gathering processes were 
conducted via WhatsApp application due to the long-distant locations between the researcher and participants. After collecting the intended data, the researcher categorized each specific theme in accord with the title of this study. After conducting this process, the researcher attempted to delineate all of these categorizations in accord with the two specific research problem formulations enacted in the previous chapter to offer renewable insights for globalized ELT practices, particularly Indonesian ELT fields concerning precise strategies to substantiate EFL teachers' identity construction according to the recited tangible narrative stories shared by the three invited EFL teachers derived from distinctive educational institutions. For the sake of research participants' confidentiality, pseudonyms were utilized in the following sections.

\section{FINDINGS AND DISCUSSION}

In this section, the researcher attempted to provide reasonable and sensible responses to the two following research problems formulated in the previous part, namely: (1) What are the specific advantageous sources sustaining novice EFL teachers to maintain their identity construction? (2) How do EFL teachers construct their identities amid unpredictable educational shifts? Concerning the obtained data, three major themes have been segmented in this study namely: (1) The Induction of Proactive Teaching Learning Engagement to be More Agentic EFL Teachers (2) The Mutual and Positive Rapport Imprinting Between Teacher-Student along with Working Colleagues Intensified Robust Identity Growth, and (3) The Continuous Rejuvenation of Professional Identity Construction to Meet with External Educational Demands. All of the overarching explications can be discerned as follows.

\section{The Induction of Proactive Teaching Learning Engagement to be More Agentic EFL Teachers (A Story from Mr. Nicholas)}

The first interesting story of second language teachers' identity construction derived from Mr. Nicholas having already experienced a wide range of teaching-learning experiences in his former educational institution named Sanata Dharma University. During his past teaching journey, he worked there as an English language tutor for English Language Education Students for 5 years. Undeniably, during this long-lengthy teaching journey, Mr. Nicholas underwent ups and downs in reconstructing, preserving, cultivating his professional identity construction as an EFL teacher. However, he had already walked in the appropriate pathways through this painstaking process by constantly participating more proactively in his prior teaching-learning community members, establishing intimate personal along with collective rapports with educational parties, reflecting more exhaustively on every beneficial suggestion addressed by senior university teachers, and becoming more selective thinkers in choosing a vast array of educational beliefs forming in his former educational institution.

There are various advantageous merits we can fully learn from this first interviewee by taking up all of those above-mentioned actions. First, the first teacher had successfully transformed into a more professional educator capable of implementing effective pedagogical methods in his classrooms. Lee (2013) as well as Sutherland, Howard, and Markauskaite (2010) believed that a higher level of EFL teachers' identity construction would allow them to become more judicious decision makers and careful planners. Furthermore, the first teacher also progressively established an intimate relationship with other colleagues enabling him to become a more strongly-motivated educator in his fields. Williams (2010) argued that EFL teachers' adept in establishing more positive and collaborative working attitudes with all educational stakeholders would prone to be more professional educators compassionate in their teaching journeys.

The last essential teaching value learned from the first teacher is the ability to infuse a more potent control our negative emotions while confronting with distinctive teaching beliefs enacted by educational institutions. The first teacher completely exhibited this precise teaching-learning value to be a more agentive, professional, and compassionate EFL educator since he frequently reflected more exhaustively on all the teaching-learning phenomena as well as constructive feedback occurring in his career. Salinas and Ayala (2018) exclaimed that when EFL teachers have successfully formed stronger professional identity in their teaching journeys, they will be more able to transform into more agentic educators embracing their personal and external educational beliefs proposed by their institutions. Liu and $\mathrm{Xu}$ (2011) strongly prompted EFL teachers to continually integrate their personal beliefs with the school institutions' beliefs in order to thoroughly promote better educational outcomes for all learners. 
The following interview excerpts taken from the first teacher is also resonated well with these conceptions.

[Mr. Nicholas: In my opinion, I possess a higher sense of belonging to my school teachinglearning communities. It is because in my daily basis, I work and grow in these communities and grow here. People round me help me to build my identity as a teacher and to improve myself and others. Therefore, the communities around me are just like my family and home in which I can develop myself and help each other.]

[Mr. Nicholas: Reengaging in my teaching journeys I how experience some influential past events which I can My first identity construction. Through others, my identity has been constructed because I can see the examples around me. I used to learn from others, both from their success and mistakes. I always value all of my past events as my learning process, both ups and downs.]

[Mr. Nicholas: I think that the beliefs in my school institutions have rejuvenated my identity constructions as a teacher. Directly or indirectly, they affect my point of view and the construction of my identity. Their beliefs, whether it is organizational, political, or socio cultural, have affected my identity construction and perspective.]

[Mr. Nicholas: The beliefs in our environment must be both in harmony or contradictory with my personal beliefs. Therefore, I have to take the good ones and eliminate the bad. By doing this, I can learn from my environment and others effectively without having the bad impact in my life.]

\section{The Mutual and Positive Rapport Imprinting Between Teacher-Student along with Working Colleagues Intensified Robust Identity Growth (A Story from Miss. Febiola)}

The second teacher also enjoyed a robust identity development of her whole teaching career due to the sincere acceptance of both good and bad things happening in her teaching journey. As a result, Miss. Febiola had become a more professional educator. This matter is indispensably crucial since second language teacher's identity construction is closely related to three major events namely proactively participating in a wide variety of educational communities, disseminating more mutual sharing with other working counterparts to broaden each other's understanding, and becoming more adaptable in various educational circumstances. Celik and Servet (2020) argued that to be more openminded, agentic, and professional future EFL educators, teachers are commissioned to be more proactive participants, mutual collaborators, and adept self-adjustors in their teaching-learning communities.

Following the aforementioned essential educational value, the second teacher also fully acknowledged that another crucial positive matter sustaining her identity formation during the teaching practicum placement is active learning participation, significant learning improvements, and continual learning enthusiasm shown by the learners. In her view, all the positive matters strongly motivated her to actualize the best actions to readily prepare learners to reach their dreams in the future. As a result, the educational quality and desired learning outcomes have been attained simultaneously through meaningful teaching-learning processes. Xu (2013) argued that when novice EFL teachers had fully integrated all of the appropriate teaching-learning values forming in their existing classroom circumstances and fully established more positive rapports with learners, their knowledge together with identity formation would be elevated as well. Keskin (2020) also believed that the mutual relationships with learners along with qualified teaching should be ingrained fully by teachers by constantly reflecting on their previous actions.

The second teacher also appreciated the values, beliefs, and traditions instilled by her school institution. For example, she has become more tolerant while listening to other teaching placement colleagues' and senior teachers' distinctive opinions. For her, the most important matter is the capabilities to work mutually with other people possessing a vast array of perspectives and implement all of those selected rewarding values to be implanted in her particular classroom learning vicinities to constantly promote high-quality teaching-learning processes. Kumazawa (2013), Schaefer (2013), as well as Kayi-Aydar (2019) claimed that since the formation of language teacher identity construction is closely associated with the dynamic educational concepts, EFL teachers are advocated to play their current educational roles as agentic educators striving to induce striking educational influences in their particular institutions by correlating their personal educational beliefs with the external educational beliefs. Ruohotie-Lyhty (2013) also suggested novice EFL teachers inculcating a higher level of professional identity construction at the onset of their teaching careers to be more competent educators 
and agents of changes adept in adapting their personal as well as teaching-learning community beliefs worthwhile to be invested in their specific classroom learning surroundings. Dikilitas and Yayli (2018) also suggested that both internal and external educational values should be well-ingrained within professional EFL teachers to make them become more professional educators. The following second teacher's interview excerpts echoed with these aforementioned contentions.

[Miss. Febiola: In the classroom community, I feel that I belong to a class where the students are eager to learn and think of English as a fun subject. This makes me feel supported and I find it easy to support student learning.]

[Miss. Febiola: I just try to keep in touch with my fellow interns because our office is separate from the teacher's room. I think this is one of the factors that causes us to be less involved in the community like teachers. However, I always try to always be in touch with the English teacher to discuss preparation, experiences, developments, and obstacles during teaching practice.]

[Miss. Febiola: The experience of feeling successful in teaching, being loved by students, failing in teaching, and being disappointed. Two very different events that I experienced. This experience certainly supports my development as a teacher. That through this experience we must remain ourselves by showing our abilities and resilience and showing our vulnerability as teachers. I always learn through various teaching experiences both at school as a formal institution, or teaching informally outside of school.]

[Miss. Febiola: During my internship, I am better able to excel with culture and others, or to be more tolerant of the natural and social surroundings. Building a teacher's identity that is friendly, openminded, and polite is an example that is built during teaching.]

[Miss. Febiola: Teachers must be able to have emotional relationships with students and colleagues, and they must also be ready and responsive to challenges in order to better construct a stronger professional identity.]

\section{The Continuous Rejuvenation of Professional Identity Construction to Meet with External Educational Demands (A Story from Mr. Hardi)}

The third invited teacher had ingrained a higher sense of belonging to his particular school institution resulted in more meaningful teaching-learning practices. He further mentioned the critical importance of preserving a positive relationship with colleagues, learners, parents, and school superiors since their reinforcement can significantly motivate him to impart his best work ethics in educational fields. Trent (2015) argued that the robust establishment of EFL teachers' professional identity had impinged upon personal commitment, mutual rapport with colleagues, perseverance, and teaching successfulness. In contrast, one of the serious hindrances potentially obstructing EFL teachers' professional identity formation according to the second teacher is the inability to impart precise responses for learners' direct inquiries in the classroom contexts. Based on his view, this kind of uneasy teaching-learning venture may create a higher sense of humiliation, lower self-confidence, and the inhibition of further professional identity construction. Yuan and Lee (2015) suggested teacher training and education program to continually contextualize the practicum teaching experiences with real-time teaching enterprises in the tangible school circumstances for novice EFL teachers to arm them with a higher degree of self-confidence, resilience, and professional identities in handling varied challenging classroom contexts. Goktepe and Kunt (2020) also advised educational parties to be more supportive of novice EFL teachers' professional identity growth by providing them with a considerable number of learning to teach opportunities in which they can foster their agency, independence, and confidence, which in turn, bolstering their existing professional identity formation.

Another interesting strand of discovery found out from the third teacher is his capabilities, willingness, and commitment to rejuvenate his professional identity formation in relation to external educational policies established by his English institution. By doing so, he will become a more resilient teacher who are not easily giving up while encountering various taxing educational obstacles. Barkhuizen (2017) argueed that EFL teachers' professional identity formation needed to be considered as a changeable construct in which the successful establishment of it depended on complex educational contexts. In a similar vein, Lee and Schallert (2016) repudiated that the strong establishment of EFL teachers' professional identity was also influenced by external factors occurring in their school institutions. In a specific case, the conservative educational policies can terrifically hinder EFL teachers' identities since they will not have adequate opportunities to gain their ownership as professional educators. Thus, the third teacher highly recommended educational institutions to allow 
EF teachers to design their lesson plans, teaching-learning materials, and classroom regulations independently as long as they are closely attached to the school institutions' regulations. Mirzaee and Aliakbari (2018) stated that it is of critical importance for school institutions to extend some liberation for EFL teachers in creating their innovative lessons. Sardabi, Biria, and Golestan (2018) proposed that critical self-reflections should be well-applied in all educational institutions in order to ensure that EFL teachers' identity development are growing well along with the educational practices. Taylor (2017) also recommended educational institutions to address their profound attention on EFL teachers' prior teaching experiences, paradigms, and competencies to allow them to be more effective problem-solvers, judicious decision-makers, and qualified learning facilitators for their learners to learn better. All of these above-explained conceptions are strongly supported by the third teacher's excerpts as follows.

[Mr. Hardi: Yes, I do. In my opinion the school environment including our learning communities becoming one of the important things that help us to shape our identity. Therefore, having a high sense of belonging to the school communities could positively impact our development, including shaping our identity.]

[Mr. Hardi: From what I understand from your question, I always keep the working vibe comfortable for anyone. Therefore, I and my friend often throw jokes that could melt a situation that make us stressed because of the workload.]

[Mr. Hardi: The worst feeling in my teaching experience was when I can 't answer and explain in the right way to my students. That moment makes me consider that I have to do double or even triple check and prepare the material as best as I can.]

[Mr. Hardi: Every time I met a new person, organization, and working systems I felt that my identity was developed and shaped to a new better identity. It is because I am an observer that rejuvenated my identity through the experience that I got from my circle.]

\section{CONCLUSION AND RECOMMENDATION}

Taken as a whole, the robust entrenchment of EFL teachers' professional identities construction are heavily influenced by various internal and external factors enshrouding of proactive teaching engagement, agentic characteristics to promote significant educational impacts, positive rapports infused between teacher-students along with work colleagues, and the needs to juxtapose the personal beliefs with the institutional educational perspectives. Since the present study still presented a substantial number of limitations, future studies need to be conducted in delving more exhaustively regarding the mutual interplay between EFL teachers' professional identities with their agency to obtain more generalizable and robust research results functioning as a fertile ground for reinforcing Indonesian EFL teachers' professional identity development amid existing educational policy constraints continually transpiring in this nation. Further, a great number of research participants deriving from distinctive educational institutions should also be involved by integrating more complete research instruments like teacher surveys, journaling, and classroom observations functioning as a reliable complementary data gathering process accompanying EFL teachers' critical self-reflection as having been recorded in this present study. The obtained research results shed more enlightenment on the further advancement of the second language learning enterprises taking place in this archipelago since ELT experts, practitioners, educators, and policy-makers become more motivated to establish a more mutual collaborative networking in which EFL teachers' identity construction is sustainably thriving.

\section{REFERENCES}

Avillanova, A. A., \& Kuswandono, P. (2019). English teacher professional development in Indonesia: The challenges and opportunities. English Review: Journal of English Education, 8(1), 41-50.

Barkhuizen, G. (2017). Language teacher identity research. Reflections on language teacher identity research, 1-11.

Beauchamp, C., \& Thomas, L. (2011). New teachers' identity shifts at the boundary of teacher education and initial practice. International Journal of Educational Research, 50(1), 6-13.

Canagarajah, A. S. (2012). Teacher development in a global profession: An autoethnography. Tesol Quarterly, 46(2), 258-279. 
Çelik, O. T., \& Servet, A. T. İ. K. (2020). Prospective Teacher Training Program in Turkey: A Meta Synthesis Study. Eğitimde Nitel Araştırmalar Dergisi, 8(2), 539-564.

Clandinin, D. J., Steeves, P., \& Caine, V. (Eds.). (2013). Composing lives in transition: A narrative inquiry into the experiences of early school leavers. Emerald Group Publishing.

Cuéllar, L., \& Oxford, R. L. (2018). Language teachers' emotions: Emerging from the shadows. In Emotions in second language teaching (pp. 53-72). Springer, Cham.

Daley, C. N., Bolchini, D., Varrier, A., Rao, K., Joshi, P., Blackburn, J., ... \& Holden, R. J. (2018, September). Naturalistic decision making by older adults with chronic heart failure: an exploratory study using the critical incident technique. In Proceedings of the human factors and ergonomics society annual meeting (Vol. 62, No. 1, pp. 568-572). Sage CA: Los Angeles, CA: SAGE Publications.

Darvin, R., \& Norton, B. (2015). Identity and a model of investment in applied linguistics. Annual review of applied linguistics, 35, 36-56.

Diasti, K. S. (2021). Constructing Professional Identity: Investigating Stress Factors and Resilience Experienced by EFL Novice Teachers. Scholaria: Jurnal Pendidikan dan Kebudayaan, 11(1), $1-10$.

Diasti, K. S., \& Kuswandono, P. (2020). "Thriving through Reflecting": Current Perspective on Teacher Professional Development Research in Asia Context. JET (Journal of English Teaching), 6(3), 220-231.

Dikilitaş, K., \& Yaylı, D. (2018). Teachers' professional identity development through action research. ELT Journal, 72(4), 415-424.

Farrell, T. S. (2011). Exploring the professional role identities of experienced ESL teachers through reflective practice. System, 39(1), 54-62.

Farrell, T. S. (2012). Novice-service language teacher development: Bridging the gap between preservice and in-service education and development. Tesol Quarterly, 46(3), 435-449.

Goktepe, F. T., \& Kunt, N. (2020). "I'll do it in my own class": novice language teacher identity construction in Turkey. Asia Pacific Journal of Education, 1-16.

Golombek, P., \& Doran, M. (2014). Unifying cognition, emotion, and activity in language teacher professional development. Teaching and Teacher Education, 39, 102-111.

Kanno, Y., \& Stuart, C. (2011). Learning to become a second language teacher: Identities-inpractice. The Modern Language Journal, 95(2), 236-252.

Kayi-Aydar, H. (2019). Language teacher identity. Language Teaching, 52(3), 281-295.

Keskin, A. (2020). An investigation of Turkish foreign language teachers' perception of professional identity (Master's thesis, Çağ Üniversitesi Sosyal Bilimler Enstitüsü).

Kumazawa, M. (2013). Gaps too large: Four novice EFL teachers' self-concept and motivation. Teaching and Teacher Education, 33, 45-55.

Kuswandono, P. (2014). University mentors' views on reflective practice in microteaching: Building trust and genuine feedback. Reflective Practice, 15(6), 701-717.

Lasky, S. (2005). A sociocultural approach to understanding teacher identity, agency and professional vulnerability in a context of secondary school reform. Teaching and teacher education, 21(8), 899-916.

Lee, I. (2013). Becoming a writing teacher: Using "identity" as an analytic lens to understand EFL writing teachers' development. Journal of Second Language Writing, 22(3), 330-345.

Lee, S., \& Schallert, D. L. (2016). Becoming a teacher: Coordinating past, present, and future selves with perspectival understandings about teaching. Teaching and Teacher Education, 56, 72-83. 
Investigating Indonesian Novice EFL Teachers' Perceptions On Their Identity Construction (Kristian F. Wijaya)

Lindahl, K., \& Yazan, B. (2019). An identity-oriented lens to TESOL teachers' lives: Introducing the special issue. TESOL Journal, 10(4), 1-5.

Liu, Y., \& Xu, Y. (2011). Inclusion or exclusion? A narrative inquiry of a language teacher's identity experience in the 'new work order'of competing pedagogies. Teaching and Teacher Education, 27(3), 589-597.

Livingston, K. (2016). Developing teachers' and teacher educators' professional identity in changing contexts. European Journal of Teacher Education, 39(4), 401-402.

Martel, J., \& Wang, A. (2015). Language teacher identity. The Routledge handbook of educational linguistics, 289-300.

Mawardi, M. (2012). The Needs Analysis of Training for Elementary School Teachers (Prior Analysis to the Research of Professional and Pedagogical Competencies Development in Civics Education). Dewantara, 1(1), 241190.

Mirzaee, A., \& Aliakbari, M. (2018). "They Now Respect Me and Send Me to the Best Schools!": Identity Construction of an Iranian EFL Teacher. Critical Inquiry in Language Studies, 15(1), 21-42.

Miyahara, M. (2015). Emerging self-identities and emotion in foreign language learning: A narrativeoriented approach (Vol. 89). Multilingual Matters.

Patton, K., \& Parker, M. (2017). Teacher education communities of practice: More than a culture of collaboration. Teaching and Teacher Education, 67, 351-360.

Reeves, Jenelle, Teacher identity work in neoliberal schooling spaces (2018). Faculty Publications: Department of Teaching, Learning and Teacher Education. 370.

Ruohotie-Lyhty, M. (2013). Struggling for a professional identity: Two newly qualified language teachers' identity narratives during the first years at work. Teaching and teacher education, 30, 120-129.

Salinas, D., \& Ayala, M. (2018). EFL student-teachers' identity construction: A case study in Chile. How, 25(1), 33-49.

Sardabi, N., Biria, R., \& Golestan, A. A. (2018). Reshaping Teacher Professional Identity through Critical Pedagogy-Informed Teacher Education. International Journal of instruction, 11(3), 617-634.

Schaefer, L. (2013). Beginning teacher attrition: A question of identity making and identity shifting. Teachers and Teaching, 19(3), 260-274.

Song, J. (2016). Emotions and language teacher identity: Conflicts, vulnerability, and transformation. TESOL quarterly, 50(3), 631-654.

Sutherland, L., Howard, S., \& Markauskaite, L. (2010). Professional identity creation: Examining the development of beginning preservice teachers' understanding of their work as teachers. Teaching and teacher education, 26(3), 455-465.

Taylor, L. A. (2017). How teachers become teacher researchers: Narrative as a tool for teacher identity construction. Teaching and Teacher Education, 61, 16-25.

Trent, J. (2015). Towards a multifaceted, multidimensional framework for understanding teacher identity. Advances and current trends in language teacher identity research, 5, 44-58.

Williams, J. (2010). Constructing a new professional identity: Career change into teaching. Teaching and Teacher Education, 26(3), 639-647.

$\mathrm{Xu}, \mathrm{H}$. (2013). From the imagined to the practiced: A case study on novice EFL teachers' professional identity change in China. Teaching and Teacher Education, 31, 79-86. 
Scholaria: Jurnal Pendidikan dan Kebudayaan, Vol. 12 No. 1, Januari 2022: 9-19

Yuan, R., \& Lee, I. (2015). The cognitive, social and emotional processes of teacher identity construction in a pre-service teacher education programme. Research Papers in Education, 30(4), 469-491.

Zembylas, M. (2003). Interrogating "teacher identity": Emotion, resistance, and selfformation. Educational theory, 53(1), 107-127. 